\section{Studies on bird diversity of Overa- Aru Wildlife Sanctuary of Jammu and Kashmir, India}

\section{Sameer Ahmad Khah ${ }^{1}$, R.J. Rao ${ }^{2}$ \& Khursheed Ahmad Wani ${ }^{3}$}

1,2 Department of Environmental Science, Jiwaji University, Gwalior, Madhya Pradesh 474011, India

${ }^{3}$ Department of Environmental Science, ITM University, Gwalior Madhya Pradesh 474001, India

Email: 1 samkhahevs@gmail.com, ${ }^{2}$ soszool@rediffmail.com, ${ }^{3}$ wanikhursheed83@gmail.com (corresponding author)

The Overa-Aru Wildlife Sanctuary (WS) is one of the most important protected areas of the state of Jammu and Kashmir and lies within the distribution range of the endangered Hangul Cervus elaphus hanglu. This Sanctuary is the habitat of different species of birds during different seasons. The avian diversity of the state varies seasonally and available data suggests the existence of 358 species of birds belonging to 179 genera, 51 families under 16 orders. Eight species of sympatric warblers, Simla Black Tit Parus rufonuchalis, Rufous-belled Crested Tit Parus rubidiventris, Crested Black Tit Parus melanolophus were abundant, found close to the tree line, and breed

Date of publication (online): 26 October 2012

Date of publication (print): 26 October 2012

ISSN $0974-7907$ (online) | 0974-7893 (print)

Editor: Rajiv S. Kalsi

Manuscript details:

Ms \# 02899

Received 02 August 2011

Final received 16 June 2012

Finally accepted 14 September 2012

Citation: Khah, S.K., R.J. Rao \& K.A. Wani (2012). Studies on bird diversity of Overa-Aru Wildlife Sanctuary of Jammu and Kashmir, India. Journal of Threatened Taxa 4(13): 3228-3232.

Copyright: (c) Sameer Ahmad Khah, R.J. Rao \& Khursheed Ahmad Wan 2012. Creative Commons Attribution 3.0 Unported License. JoTT allows unrestricted use of this article in any medium for non-profit purposes, reproduction and distribution by providing adequate credit to the authors and the source of publication.

Acknowledgements: The authors are indebted to Chief Wildlife Warden Department of Wildlife Protection Jammu and Kashmir, officers and field staff for their cooperation and support. We are highly thankful to Head Department of Zoology, Jiwaji University, Gwalior for providing all the facilities for the present work.

ZooBank urn:Isid:zoobank.org:pub:D50D6B54-3BF6-4B43-B3E7CE683EA52456

OPEN ACCESS | FREE DOWNLOAD

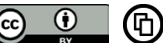

in the Overa-Aru (Price \& Jamdar 1989, 1990, 1991). However, Stattersfield et al. (1998) have reported 11 restricted range species, four or more of which have been found in the sanctuary. Birdlife International (2001) reported that the only threatened species in Overa-Aru WS is the Kashmir Flycatcher Ficedula subrubla, a restricted range species and it was found wintering in Sri Lanka and in the Western Ghats (Ali \& Ripley 1987). The present study is an attempt to list the bird species of Overa-Aru WS, which can be useful as baseline information for future conservation and management of the habitat.

\section{Study Area}

This study was carried out in the Overa-Aru Wildlife Sanctuary located in the Himalayan biogeographical zone to the southeast of Srinagar, with the southern boundary at Pahalgam in Anantnag District (Image 1). It is a famous tourist attraction in this region. The Sanctuary lies in Lidder Valley Forest Division surrounded by Sindh Forest Division in the north; Lidder Forest in the south; Pahalgam in the east; and Dachigam National Park in the west. The Sanctuary is located at an altitude of 2100-5425 m between

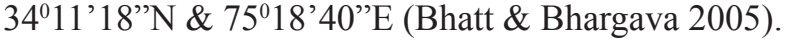

The Sanctuary is named after two villages, Overa and Aru (Suhail 2000). Overa-Aru is an old sanctuary declared under Dogra rule in 1945. At that time the Sanctuary covered only $32 \mathrm{~km}^{2}$ which was later extended to $392 \mathrm{~km}^{2}$ when Aru forest was included in the year 1981. Initially, the same order designated the area as a biosphere reserve of $425 \mathrm{~km}^{2}$ under the "Man and Biosphere Programme", but neither the Government of India nor UNESCO accepted the designation and finally the State Government declared the whole area as a wildlife sanctuary (Suhail 2000). The dominant trees species were Cedrus deodara, Pinus griffithii, Abies pindrow, Aesculus indica etc. The major shrub species were Indigofera heterantha, Viburnum sp., Sorbaria tomentosa etc. The ground cover was very rich and dicotyledonous herbs dominated, comprising of Rumex patientia, Primula sp., Anemone sp.

\section{Methods}

Birds were surveyed for about one week every 


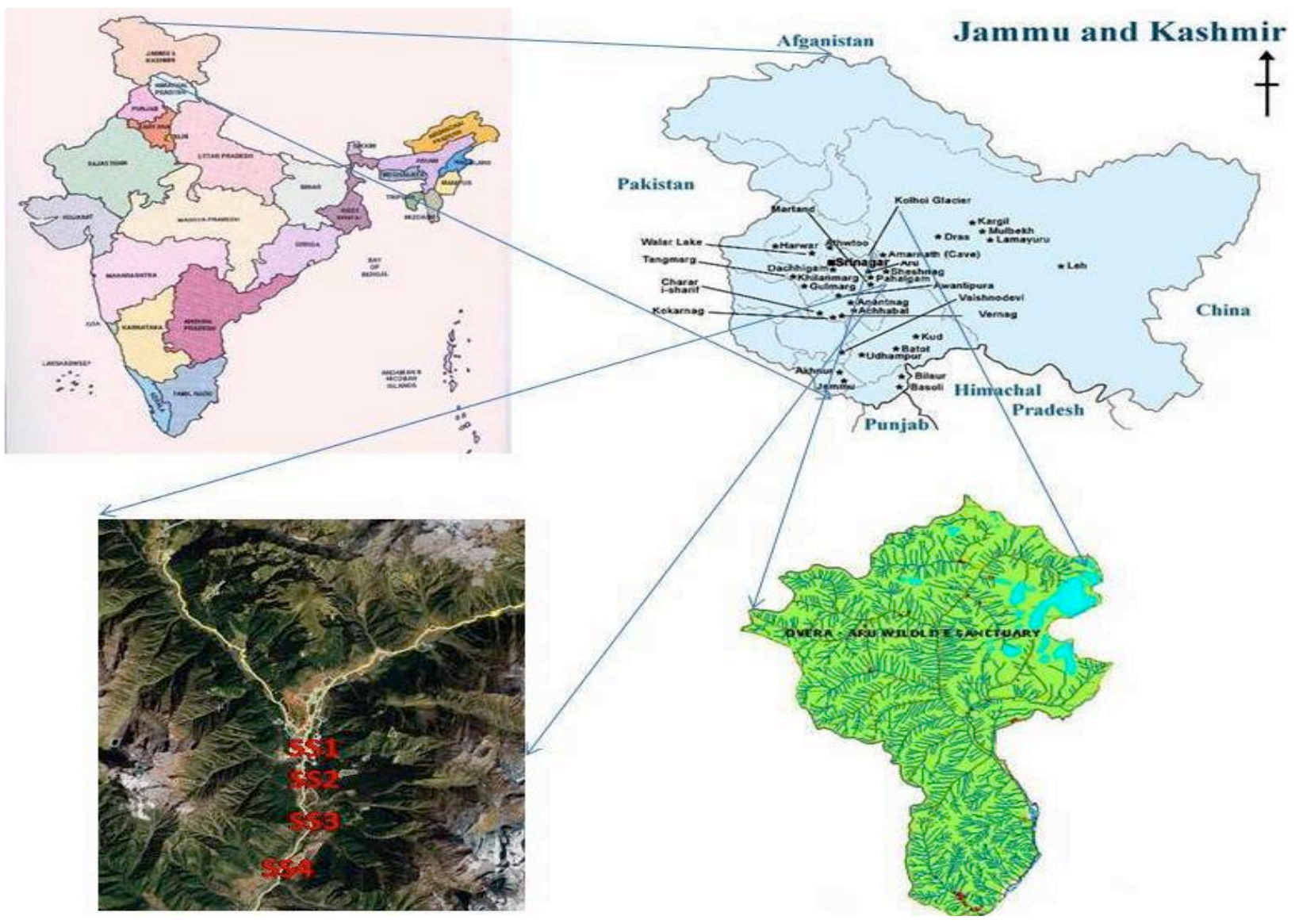

Figure 1. Study area

month from October 2010 to June 2011. The surveys were conducted on foot and observations were made with 7-21x40 binoculars, mainly in the morning and evening. Grimmett et al. (1998) and Ali \& Ripley (1987) were used for identification, and in many cases photographs were taken in order to confirm the identification.

For the present study, eight study sites were selected, four of which were in the Overa part and the other four from the Aru part of the sanctuary. The study sites were selected and surveyed on the basis of harbouring varied biodiversity. Frequent occurrence of different bird species in these areas during spring and summer seasons was another reason for the selection of these areas. The birds were categorised into abundant or very common, common and fairly common based on their abundance and their feeding habits as in Ali \& Ripley (1987). Various research advisors, local communities, field staff of Overa-Aru WS and other key organizations were consulted during the study period for data collection.

\section{Bird species diversity and evenness}

Species diversity was calculated using the ShannonWeiner Diversity Index (Shannon \& Weaver 1949).

$\mathrm{H}=-\sum_{\mathrm{i}=1}^{\mathrm{s}} \mathrm{p}_{\mathrm{i}} \log \mathrm{p}_{\mathrm{i}}$

Where $\mathrm{i}=1$

$\mathrm{H}$ - Symbol for the diversity in a sample of S species $\mathrm{S}$ - The number of species in the sample

$\mathrm{Pi}$ - relative abundance of ith species measured, = $n_{i} / \mathrm{N}$

$\mathrm{N}$ - Total number of individuals of all species

$n_{i}$ - number of individuals of ith species

$\log$ - natural $\log$

\section{Results and Discussion}

The avifauna of the Overa-Aru WS includes a large number of birds both resident and migratory. Resident as well as migratory birds were found in the lower areas from March-September. A total of 702 individual birds representing 29 species, 22 families 
and five orders, were observed from the sanctuary during the study (Table 1). Family Motacillidae had the highest number of species (six) followed by Sturnidae, Muscicapidae, Passeridae, Columbidae with two species each. Fifteen families were represented by single species each (Appendix 1).

Price et al. (2003) reported a list of 70 species of birds in the Overa-Aru WS in contrast to 117 bird species recorded in or around the sanctuary. Eighty nine species breed within its boundaries as listed by Price \& Jamdar (1990).

More than $70 \%$ of the birds were breeding residents in the Overa-Aru WS. Species such as Rock Bunting E. cia, Jungle Crow C. macrorhynchos, Common Stonechat Saxicola torquatus, Oriental Turtle Dove Streptopelia orientalis, Russet Sparrow Passer rutilans and various species of warblers were found breeding in the lower areas of the sanctuary. Price \& Jamdar $(1989,1991)$ reported eight species of sympatric warblers breeding in Overa-Aru.

Among foraging groups, the bird community of insectivores dominated, representing more than $72 \%$ of the species and $65 \%$ of the individuals. Omnivores comprised more than $10 \%$ of the species and $22 \%$ of the individuals while granivores represented more than $10 \%$ of the species and $8 \%$ of the individuals. Carnivores and frugivores were least represented in this study of avian community of Overa-Aru WS.

Diversity Indices of both resident and migratory birds of Overa-Aru were calculated by the ShannonWiener method (Fig. 1). The species diversity index fluctuated from 0.097 (site-1) to 0.064 (site-5). The highest diversity was shown in site-1, while site- 5 had the lowest diversity. Apart from the diversity, species evenness has shown variation in the first five sites with values of 0.061 (site-2), 0.073 (site-1), 0.067 (site-3), 0.051 (site-4) and 0.044 (site-5) with respect to each other. Site- 6 , site- 7 and site- 8 have shown almost the same species evenness to each other. The variation in species diversity and species evenness at various sites may be due to the influx of tourists, vehicles and local people in and near the sanctuary and the availability of food to the birds. The Overa-Aru WS is located at Pahalgam which is a tourist hub in Jammu and Kashmir.

The anthropogenic activities such as parking lots, housing developments and agricultural fields may have changed the diversity in the area which is well reflected by the species composition before human intervention (Sax \& Gaines 2003).

\section{REFERENCES}

Ali, S. \& S.D. Ripley (1987). Compact Handbook of the Birds of India and Pakistan (2nd edition). Oxford University Press, Delhi, 72-92.

Bhatt, S.C. \& G.K. Bhargava (2005). Land and People of Indian States and Union Territories - Vol. II. Jammu \& Kashmir. Kalpas Publication, Delhi, 60pp.

Birdlife International (2001). Threatened Birds of Asia - Red Data Book. Birdlife International, Cambridge, 2214-2216.

Grimmett, R., C. Inskipp \& T. Inskipp (1998). Birds of The Indian Subcontinent. Oxford University Press, Delhi, 591$615 \mathrm{pp}$.

Price, T. \& N. Jamdar (1989). Where Eight Leaf Warblers Breed. Hornbill 2: 7-11.

Price, T. \& N. Jamdar (1990). The Breeding birds of Overa

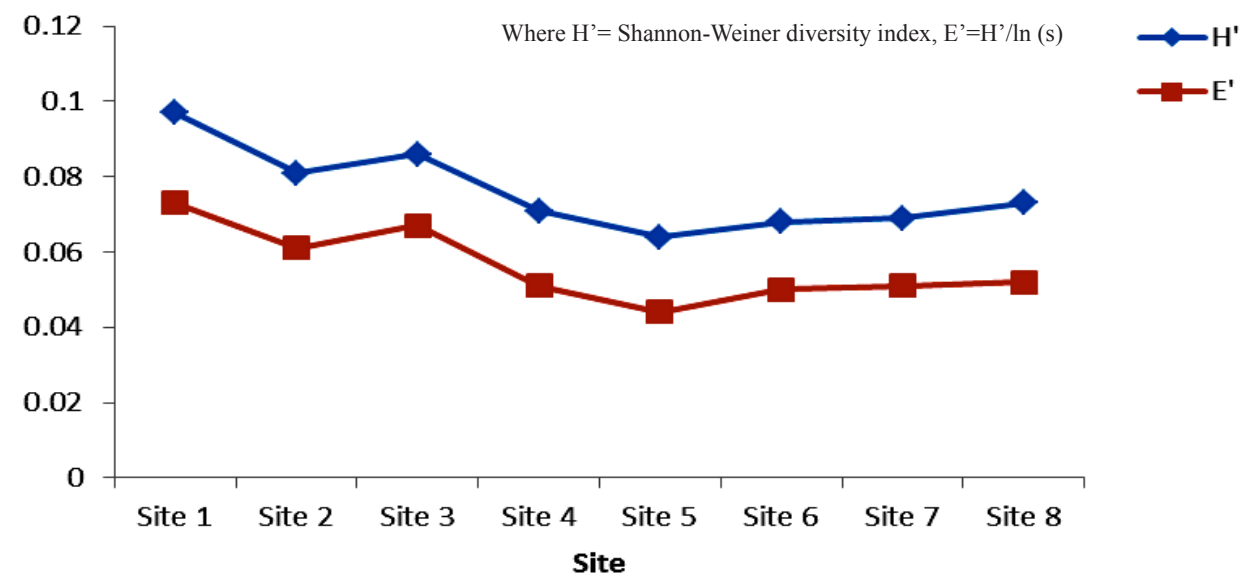

Figure 1. Shannon diversity index and evenness of birds in Overa-Aru Wildlife Sanctuary 
Table 1. The migratory status, feeding habits, abundance and status of avifauna of Overa-Aru Wildlife Sanctuary

\begin{tabular}{|c|c|c|c|c|c|}
\hline & Scientific name & Common name & $\begin{array}{l}\text { Migratory } \\
\text { status }\end{array}$ & $\begin{array}{c}\text { Feeding } \\
\text { habit }\end{array}$ & Status \\
\hline 1 & Corvus macrorhynchos & Jungle Crow & $\mathrm{R}, \mathrm{A}$ & $\mathrm{O}$ & 2 \\
\hline 2 & Sturnus vulgaris & Common Starling & $\mathrm{W}, \mathrm{P}, \mathrm{M}, \mathrm{R}^{*}$ & $\mathrm{~F}$ & 1 \\
\hline 3 & Acridotheres tristis & Common Myna & W,A,M & I & 2 \\
\hline 4 & Saxicola torquatus & Common Stone Chat & $\mathrm{R}, \mathrm{M}, \mathrm{P}$ & I & 2 \\
\hline 5 & Rhyacornis fuliginosa & Plumbeous Water-redstart & $\mathrm{R}$ & $\mathrm{O}$ & 1 \\
\hline 6 & Passer rutilans & Russet Sparrow & A & G & 3 \\
\hline 7 & Motacilla citreola & Citrine Wagtail (Image 2) & M & 1 & 2 \\
\hline 8 & Streptopelia orientalis & Oriental Turtle Dove & $\mathrm{R}, \mathrm{M}, \mathrm{W}$ & G & 3 \\
\hline 9 & Myophonus caeruleus & Blue Whistling Thrush & $A, M$ & I & 1 \\
\hline 10 & Pycnonotus leucogenys & Himalayan Bulbul & $\mathrm{R} \cdot$ & I & 2 \\
\hline 11 & Emberiza cia & Rock Bunting & $A, M$ & 1 & 2 \\
\hline 12 & Columba livia & Rock Pigeon & $\mathrm{R}, \mathrm{A}$ & G & 1 \\
\hline 13 & Motacilla alba & White Wagtail (Image 3) & $A, M$ & 1 & 2 \\
\hline 14 & Motacilla cinerea & Grey Wagtail (Image 4) & $A, M, W$ & 1 & 2 \\
\hline 15 & Motacilla flava & Yellow Wagtail (Image 5) & $\mathrm{B}, \mathrm{W}, \mathrm{P}$ & I & 1 \\
\hline 16 & Anthus roseatus & Rosy Pipit & $\mathrm{A}, \mathrm{M}, \mathrm{W}$ & 1 & 2 \\
\hline 17 & Prunella rubeculoides & Robin Accentor & A & I & 3 \\
\hline 18 & Lanius schach & Long Tailed Shrike & $\mathrm{R} \cdot \mathrm{M}$ & I & 2 \\
\hline 19 & Phylloscopus occipitalis & Western Crowned Warbler & $\mathrm{M}$ & I & $1-3$ \\
\hline 20 & Gyps himalayensis & Himalayan Griffon Vulture & A & C & 3 \\
\hline 21 & Phylloscopus affinis & Tickell's Leaf Warbler & M & I & 1 \\
\hline 22 & Carduelis spinoides & Yellow Breasted Green Finch & A & 1 & 2 \\
\hline 23 & Upupa epops & Common Hoopoe & $\mathrm{R}, \mathrm{B}, \mathrm{W}$ & 1 & 2 \\
\hline 24 & Parus major & Great Tit & $\mathrm{R}, \mathrm{A}$ & I & 1 \\
\hline 25 & Dendrocopos himalayensis & Himalayan Woodpecker & $\mathrm{N}, \mathrm{A}$ & I & 2 \\
\hline 26 & Anthus trivialis & Tree Pipit & $M, P, W$ & I & 3 \\
\hline 27 & Terpsiphone paradisi & Asian Paradise Flycatcher & $R \cdot, M, P$ & I & 3 \\
\hline 28 & Rhyacornis fuliginosa & Plumbeous Water Redstart & $A$ & I & 2 \\
\hline
\end{tabular}

Migratory status: $\mathrm{R}$ - residential, $\mathrm{W}$ - winter visitor, A - altitudinal migrant, $\mathrm{P}$ - passage migrant, $\mathrm{M}$ - migrates within the subcontinent, $\mathrm{N}$ - nea endemic, ${ }^{*}$ - localised or patchily distributed, $\bullet$ - subject to some seasonal movement or wandering.

Feeding habit: P - Piscivores, H - Herbivores, O - Omnivores, C - Carnivores, I - Insectivores, G - Granivores, F - Frugivores

Status: 1 - abundant or very common, 2 - common, 3 - fairly common

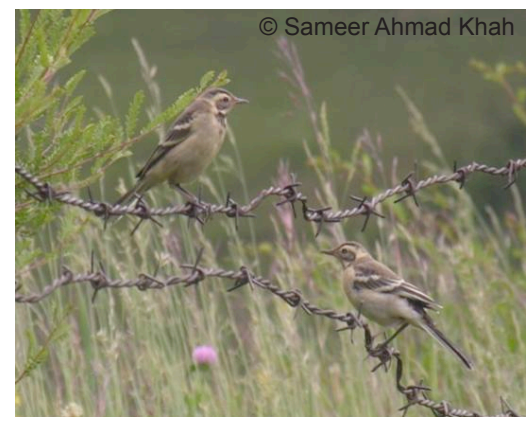

Image 2. Citrine Wagtail Motacilla citreola

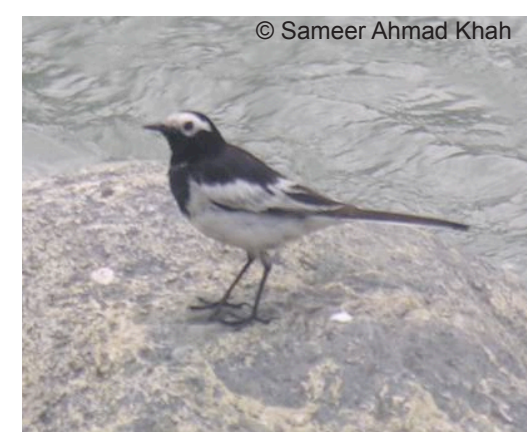

Image 3. White Wagtail Motacilla alba

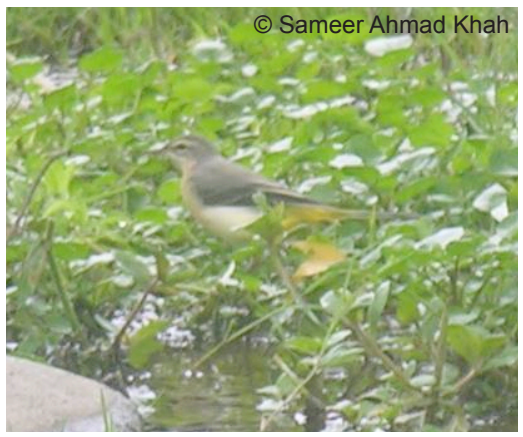

Image 4. Grey Wagtail Motacilla cinerea 
Appendix 1. Site wise population of birds in Overa-Aru Wildlife Sanctuary

\begin{tabular}{|c|c|c|c|c|c|c|c|c|c|c|c|}
\hline & Scientific name & Family & Site 1 & Site 2 & Site 3 & Site 4 & Site 5 & Site 6 & Site 7 & Site 8 & Total \\
\hline 1 & Corvus macrorhynchos & Corvidae & 4 & 2 & & 7 & 8 & 7 & 6 & 10 & 44 \\
\hline 2 & Sturnus vulgaris & Sturnidae & 1 & 8 & & 2 & 2 & 1 & & 3 & 17 \\
\hline 3 & Acridotheres tristis & Sturnidae & 2 & 6 & & 4 & 3 & 9 & 4 & 9 & 37 \\
\hline 4 & Saxicola torquatus & Muscicapidae & & & & 3 & 4 & & & 2 & 9 \\
\hline 5 & Rhyacornis fuliginosa & Muscicapidae & 10 & 8 & 4 & 10 & 4 & 6 & 2 & 6 & 50 \\
\hline 6 & Oriolus oriolus & Oriolidae & & & 7 & 4 & 9 & 8 & 2 & 8 & 23 \\
\hline 7 & Passer rutilans & Passeridae & 2 & & 5 & 3 & 5 & 5 & 3 & 4 & 27 \\
\hline 8 & Passer domesticus & Passeridae & & & & 3 & 2 & 3 & 2 & 2 & 12 \\
\hline 9 & Motacilla citreola & Motacillidae & & & 1 & & 3 & 7 & 2 & 4 & 17 \\
\hline 10 & Motacilla alba & Motacillidae & 8 & 6 & 2 & 9 & 2 & 5 & & & 32 \\
\hline 11 & Motacilla cinerea & Motacillidae & & & & & 4 & 5 & 3 & 2 & 14 \\
\hline 12 & Motacilla flava & Motacillidae & 2 & 3 & 2 & 4 & 1 & 7 & 3 & 3 & 25 \\
\hline 13 & Anthus roseatus & Motacillidae & 5 & 6 & 3 & 4 & 5 & 5 & 1 & 2 & 29 \\
\hline 14 & Anthus trivialis & Motacillidae & 3 & 2 & 4 & 2 & 3 & 13 & & 3 & 30 \\
\hline 15 & Myophonus caeruleus & Turdidae & 2 & 1 & 2 & 2 & 2 & 4 & 3 & 3 & 19 \\
\hline 16 & Pycnonotus leucogenys & Pycnonotidae & 2 & 1 & 2 & 1 & 7 & 7 & 2 & 5 & 27 \\
\hline 17 & Emberiza cia & Emberizidae & 2 & 2 & & 2 & 1 & & 2 & 2 & 11 \\
\hline 18 & Prunella rubeculoides & Prunellidae & & 2 & 3 & 2 & 1 & 4 & 2 & 2 & 16 \\
\hline 19 & Terpsiphone paradisi & Monarchidae & 2 & 3 & 2 & & 3 & 2 & 1 & 3 & 17 \\
\hline 20 & Parus major & Paridae & 2 & 1 & 1 & 1 & & & 2 & & 7 \\
\hline 21 & Lanius schach & Laniidae & 25 & 13 & 15 & 4 & 3 & & & & 60 \\
\hline 22 & Carduelis spinoides & Fringillidae & & 2 & & & 8 & 3 & 4 & 2 & 19 \\
\hline 23 & Phylloscopus occipitalis & Phylloscopidae & 3 & 1 & 2 & 2 & 2 & & & & 10 \\
\hline 24 & Phylloscopus affinis & Phylloscopidae & 1 & 1 & 2 & 1 & 4 & 3 & 2 & 2 & 16 \\
\hline 25 & Streptopelia orientalis & Columbidae & 2 & 2 & 1 & 1 & 1 & 4 & 1 & 1 & 13 \\
\hline 26 & Columba livia & Columbidae & 1 & 6 & 4 & 2 & 12 & & 2 & 6 & 33 \\
\hline 27 & Gyps himalayensis & Accipitridae & & & & & 1 & 2 & 1 & 1 & 4 \\
\hline 28 & Upupa epops & Upupidae & 2 & & & 2 & 4 & 2 & 8 & 2 & 20 \\
\hline \multirow[t]{2}{*}{29} & Dendrocopos himalayensis & Picidae & 20 & 10 & 4 & 8 & 3 & 6 & 3 & 10 & 64 \\
\hline & Total & & 101 & 86 & 66 & 83 & 107 & 117 & 61 & 93 & 702 \\
\hline
\end{tabular}

Wildlife Sanctuary, Kashmir. Journal of the Bombay National History Society 87: 1-15.

Price, T. \& N. Jamdar (1991). Breeding of eight species of phylloscopus warblers in Kashmir. Journal of the Bombay National History Society 88: 242-255.

Price, T., J. Zee, K. Jamdar \& N. Jamdar (2003). Bird species diversity along the Himalaya: a comparison of Himachal Pradesh with Kashmir. Journal of the Bombay Natural History Society 100: 394-410.

Shannon, C.E. \& W. Weaver (1949). The Mathematical Theory of Communication. University of Illinois Press, $117 \mathrm{pp}$.

Sax, D.F. \& D. Steven (2003). Gaines Species diversity: from global decreases to local increases. TRENDS in Ecology and Evolution 18: 561-566.

Stattersfield, A.J., A.J. Crosby, D.C. Long \& Wege (1998). Endemic Bird Areas of The World Priorities for Biodiversity conservation. BirdLife International, Cambridge, U.K., 19-26pp.

Suhail, I. (2000). Overa-Aru Wildlife Sanctuary: Management Plan: 2001-2006. Department of Wildlife Protection, Srinagar, 508-510pp.

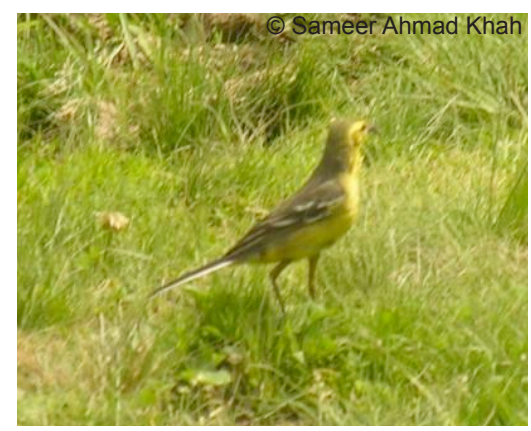

Image 5. Yellow Wagtail Motacilla flavia 